\section{Testable claims}

\section{Lee Loevinger}

Being an Effective Expert Witness: The Technologist in the Courtroom. By Derek A. Smith. Thames Publishing, 14 Barlby Road, London W10 6AR, UK. 1993. Pp. 297. $£ 34.50$.

DEREK Smith is a chemist, an experienced witness and a natural raconteur, who reports years of experience with literary flair. His account is particularly timely: the subject of scientific testimony has become of widespread interest in the United States following the decision in June 1993 by the Supreme Court in Daubert v. Merrell Dow Pharmaceuticals promulgating standards for admissible scientific evidence. Shepard's Expert and Scientific Evidence Quarterly has begun publication, and the American Association for the Advancement of Science and the Science and Technology Section of the American Bar Association have held a conference with the Federal Judicial Center to start a long-term experiment using Federal Rule of Evidence 706 to encourage court appointment of neutral scientists in appropriate cases. Articles and cases citing Daubert are beginning to proliferate.

Most of what is being written is by lawyers (including some judges) who explain the law to scientists or to each other. Smith is a scientist who has undertaken to explain science to lawyers and legal procedure to scientists with specific advice as to how to serve as an expert witness. His style is informal, idiomatic and lightened by frequent quotations from sources as diverse as the Bible, Shakespeare, Lewis Carroll, and Gilbert and Sullivan, some in footnotes, which are often as amusing as the text. More notably, his observations are illustrated by anecdotes of actual cases, mainly ones in which he has participated.

Smith writes in an English (as distinct from American) vernacular, referring to lawyers as solicitors, barristers and counsel (the barrister pleading a case), but the book is understandable and useful to an American interested in the subject, and there is a short glossary for those confused by the terminology. Anyway, the basics of English and American litigation are the same. The federal courts in the United States correspond to the High Court in England, the larger and more important cases tend to be filed in such courts, and about the same number of cases are filed in these courts annually in each country. More of the cases filed go to trial in the United States than in England, but the number is less than 5 per cent in both countries.

The big difference between the legal

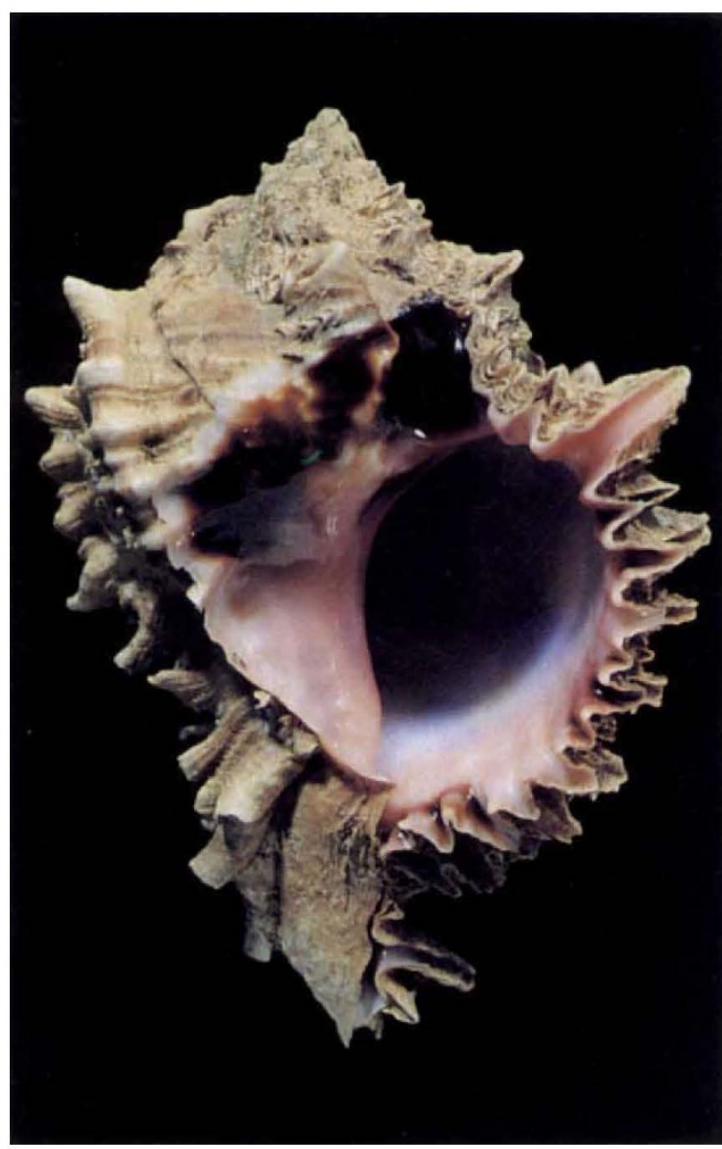

Convolutions of a smooth-lipped shell Phyllonotus regius (Muricidae; $\times 0.8$ ) from Playa Brava, Costa Rica. In A Natural History of Shells, from which this photograph is taken, Geerat J. Vemeij provides an elegantly written and beautifully illustrated account of shell construction, function and evolution, while showing how these molluscan houses give us insights into ecology and the history of life. A book that will be treasured by scientists and lay readers alike. Princeton University Press, \$29.95, £22.50. systems lies in the existence of the 50 state court systems in the United States. In England about 10 times as many cases are filed each year in the county, or lower, courts as in the High Court. In the United States more than a hundred times as many cases are filed each year in the state courts as in the federal courts.

The relationship of scientific and technical experts to lawyers and courts is much the same regardless of the court in which a case is filed. Smith relates experience in English, US and continental courts, and notes the variations. The major differences he has observed between English and American lawsuits is that in the latter there is more pre-trial discovery, including depositions; higher attorney fees; more incivility between adversaries, including more hectoring of witnesses on cross-examination; and there have been lower standards for scientific experts permitting more testimony by bogus scientists. (A footnote adds that in the United States more corporate executives have given up smoking!) Although the forms of legal procedure differ among the countries, the viewpoints and roles of scientists appear generally uniform in the Western world.

American lawyers may get some feel for the atmosphere and pace of English litigation from the descriptions in this book, but it is definitely not a lawyer's guide to English practice. Many cases are referred to by title but no legal citations are given. Although the principles expounded are valid for all varieties of expert testimony, the focus is on patent cases involving issues of chemical compounds, processes or materials. Nevertheless, the book is primarily what its title suggests - a guide to expert witnesses in technological cases. This function it fulfils very thoroughly. Both experienced and merely expectant expert witnesses will profit from reading it, as it systematically covers all aspects of that complex and important role. Lawyers and business executives who have occasion to deal with expert witnesses, or with scientific consultants, will gain valuable insight into the attitudes of scientists.

Every trial lawyer eventually formulates his own instructions to experts and other witnesses, but it is most unlikely that any has prepared such an extensive dissertation. Some may hesitate to require prospective witnesses to read such a lengthy exposition because that will increase the expert's fees. However, the book can be recommended without reservation as a trial lawyer I found nothing in it with which to disagree.

Although there is little philosophizing, Smith understands and discusses the difference between courtroom testimony and scientific publication. The last chapter considers the future of the expert witness, noting that the resolution of disputes 